\title{
APLIKASI CITRA ALOS PALSAR UNTUK PENDUGAAN SIMPANAN KARBON DI HUTAN TANAMAN AKASIA
}

\author{
(Application of alos palsar image for estimation of carbon stock in acacia forest) \\ Muhammad Abdul Qirom', M. Buce Saleh ${ }^{2}$, dan Budi Kuncahyo² \\ ${ }^{1}$ Balai Penelitian Kehutanan Banjarbaru \\ Jl. Ahmad Yani Km 28,7 Landasan Ulin, Banjarbaru, Telp./Fax. 0511-4707872 \\ Email: qirom_ma@yahoo.co.id \\ ${ }^{2}$ Fakultas Kehutanan Institut Pertanian Bogor \\ Jl. Raya Darmaga, Bogor
}

Naskah masuk : 23 September 2011; Naskah diterima : 14 Agustus 2012

\begin{abstract}
Estimation of carbon stock has direct limitations related to the speed of obtaining results, area coverage and high cost. Remote sensing can be used to estimate carbon stocks with an adequate level of accuracy. The objectives of this study are 1) to obtain the potential carbon storage of $\underline{A}$. mangium, 2) to estimate model of carbon stocks based on a radar image (backscatter value of Alos Palsar), and 3) to map potential carbon stock distribution of $\underline{\text { A. mangium at }}$ PT. Inhutani II, South Kalimantan. The method used was a direct inventory of carbon stocks by making 69 measuring plots (0.1 ha area of each plot) spread across several age. The field inventory results were used to formulate a relationship with the polarization values of the Alos Palsar. The results showed that the potential surface carbon deposit varied from 32.03 to 46.10 tons/ha with an average value of 39.06 tons/ha. The total potential carbon stock per ha ranged from 35.48 to 51.01 tons/ha with an average of 43.24 tons/ha. The best allometric relationship between carbon stock and the polarization values HH and HV of the Alos Palsar image was Carbon Deposit $=292+2.00 \mathrm{HH}^{2}$ $+27.1 \mathrm{HV}$ with the $R^{2}=40.9 \%$. Potential carbon storage based on Alos Palsar image ranged between $40-80$ tons/ha. The result of Alos Palsar predicton is accurate so the technology can be used for measuring or monitoring of carbon stocks in plantation forest.
\end{abstract}

Keywords: Estimation, carbon, Alos Palsar image, polarization, radar

\begin{abstract}
ABSTRAK
Pendugaan persediaan karbon secara langsung mempunyai keterbatasan terkait dengan kecepatan memperoleh hasil, cakupan luasan yang terbatas dan biaya yang mahal. Penginderaan jarak jauh dapat dimanfaatkan untuk menduga persediaan karbon dengan akurasi yang cukup memadai. Tujuan penelitian ini yakni: 1) mendapatkan potensi simpanan karbon jenis A. mangium, 2) mendapatkan model penduga simpanan karbon berdasarkan citra Radar (nilai backscatter citra Alos Palsar), 3) mendapatkan peta sebaran potensi simpanan karbon jenis A. mangium di PT. Inhutani II, Kalimantan Selatan. Metode yang digunakan dengan melakukan inventarisasi persediaan karbon secara langsung yakni pembuatan plot pengukuran sebanyak 69 plot dengan luas masing-masing plot seluas 0,1 Ha tersebar pada beberapa umur. Hasil inventarisasi tersebut digunakan untuk membentuk hubungan dengan nilai polarisasi dari citra Alos Palsar. Hasil penelitian menunjukkan potensi simpanan karbon permukaan sebesar 32,03 46,10 ton/ha dengan rata-rata 39,06 ton/ha. Potensi simpanan karbon total per Ha berkisar antara 35,48 -51,01 ton/ha dengan rata-rata 43,24 ton/ha. Model alometrik terbaik hubungan antara simpanan karbon dan nilai polarisasi $\mathrm{HH}$ dan HV dari citra Alos Palsar adalah Simpanan karbon $=292+2,00 \mathrm{HH}^{2}+27,1 \mathrm{HV}$ dengan koefisien determinasi sebesar 40,9\%. Potensi sebaran simpanan karbon total terbesar berdasarkan aplikasi citra Alos Palsar yakni berkisar antara 40 - 80 ton/Ha. Penggunaan Alos Palsar untuk menduga simpanan karbon menghasilkan dugaan yang cukup akurat sehingga teknologi ini dapat digunakan untuk mengukur atau monitoring persediaan karbon pada tegakan hutan tanaman.
\end{abstract}

Kata kunci : Pendugaan, karbon, citra Alos Palsar, polarisasi, radar 


\section{PENDAHULUAN}

Luas hutan tanaman di dunia diperkirakan 130 juta ha, dengan laju pertambahan rata-rata mencapai 10,5 juta ha/tahun yang menyebar di 124 negara. Secara global, potensi hutan tanaman menyimpan karbon sebesar 11,8 Pg (Penta gram) (Winjum and Schroeder, 1997). Berdasarkan hal tersebut, hutan tanaman menjadi salah satu opsi mitigasi dalam mengurangi kenaikan karbon dioksida dan perubahan iklim global (Kraenzel etal., 2003).

Potensi hutan tanaman sebagai opsi mitigasi dapat dipelajari dengan melihat dinamika siklus karbonnya melalui pengukuran persediaan karbonnya (Jepsen, 2006). Pengukuran simpanan karbon ini dapat dilakukan baik secara langsung maupun tidak langsung (Nath et al., 2009). Pengukuran simpanan karbon secara langsung dilakukan dengan melakukan penebangan terhadap bagian tanaman yang akan diukur simpanan karbonnya. Pengukuran simpanan karbon secara tidak langsung membangun suatu persamaan alometrik (Brown, 1997; Wang, 2006; Somogyi, 2008; Navar, 2009). Kekurangan dari pengggunaan metode langsung (destructive technique) yakni membutuhkan waktu yang relatif lama dan biaya yang sangat mahal untuk dimensi yang besar (Nath et al., 2009). Kelebihan dari metode pendugaan tidak langsung yakni waktu dan biaya yang relatif lebih murah dibandingkan dengan metode secara langsung sehingga lebih banyak disukai untuk digunakan (St Clair, 1993). Saat ini, perkembangan pendugaan persediaan karbon menggunakan aplikasi teknologi penginderaan jarak jauh. Aplikasi ini dilakukan dengan menggabungkan parameter tegakan (tinggi, diameter, dan kerapatan) dengan data penginderaan jarak jauh (Morel et al., 2011).

Aplikasi ini telah dapat menggambarkan kondisi tegakan pada beberapa tipe lahan seperti perkebunan sawit (Morel et al., 2011); hutan konservasi (Berry et al., 2008); dan pendugaan simpanan karbon pada tingkat landscape (Saatchi et al., 2007) dengan akurasi yang cukup tinggi. Berdasarkan kondisi tersebut, penggunaan teknologi penginderaan jarak jauh menjadi syarat dalam pengelolaan hutan (Brown, 2002; Sritakae, 2006). Teknologi ini digunakan menduga parameter tegakan seperti biomassa batang, rata-rata diameter, kerapatan bidang dasar, kerapatan pohon, dan tinggi rata-rata (Sritakae, 2006). Keuntungan utama dari penggunaan teknologi ini adalah mudah memperkirakan persediaan karbon dengan melakukan pengamatan secara visual (Gibbs et al., 2007). Saat ini, perkembangan teknologi penginderaan jauh dapat menduga kandungan karbon baik secara global (Rokhmatullah, 2007; Gibs et al., 2007), landscape (Sulistyawati, 2006) maupun pada tingkat spesies (Dahlan et al., 2005). Citra optik dapat digunakan untuk menduga persediaan karbon. Secara umum, metode yang biasa digunakan (terutama untuk citra optik) yakni menggunakan NDVI (indeks vegetasi) sebagai variabel bebas dalam menduga persediaan karbon. Kekurangan penggunaan citra ini terkait kualitas citra yang digunakan sebagai sumber analisis datanya. Secara umum, kualitas citra optik sangat dipengaruhi oleh kondisi lingkungan pada saat peliputan seperti tutupan awan. Kekurangan ini dapat dihindarkan dengan menggunakan citra berbasis radar yang tidak terpengaruh oleh tutupan awan sehingga kualitas data yang digunakan lebih baik.

Penelitian ini dilakukan pada areal hutan tanaman A. mangium dengan beberapa tingkat umur untuk mendapatkan simpanan karbon secara langsung dan menghubungkannya dengan parameter spasial pada citra Alos Palsar. Tujuan penelitian ini yakni 1) mendapatkan potensi simpanan karbon jenis A. mangium; 2) mendapatkan model penduga simpanan karbon berdasarkan citra Radar (nilai backscatter citra Alos Palsar); 3) mendapatkan peta sebaran potensi simpanan karbon jenis A. mangium di PT. Inhutani II, Kalimantan Selatan.

\section{BAHAN DAN METODE}

\section{A. Lokasi Penelitian}

Penelitian ini dilakukan di PT. Inhutani II Unit Semaras Kalimantan Selatan (Gambar 1). Lokasi penelitian ini didominasi oleh tanah podsolik merah kuning dan memiliki lereng yang relatif datar.

Pada saat ini, hutan tanaman ini memasuki rotasi kedua. Pembangunan hutan tanaman ini menggunakan beberapa persiapan lahan yakni dobrak (persiapan lahan mekanis), Tanpa Olah Tanah (TOT), dan sistem tumpangsari. Jarak tanam yang digunakan dalam penamanan $A$. mangium yakni $4 \mathrm{~m} \times 2 \mathrm{~m}$ dan $3 \mathrm{~m} \times 3 \mathrm{~m}$, tetapi pada rotasi kedua penggunaan jarak tanam $4 \times 2$ $m$ tidak digunakan. Hasil penelitian Lazuardi (2009) menunjukkan bahwa lokasi ini mempunyai kualitas tapak yang sedang. 


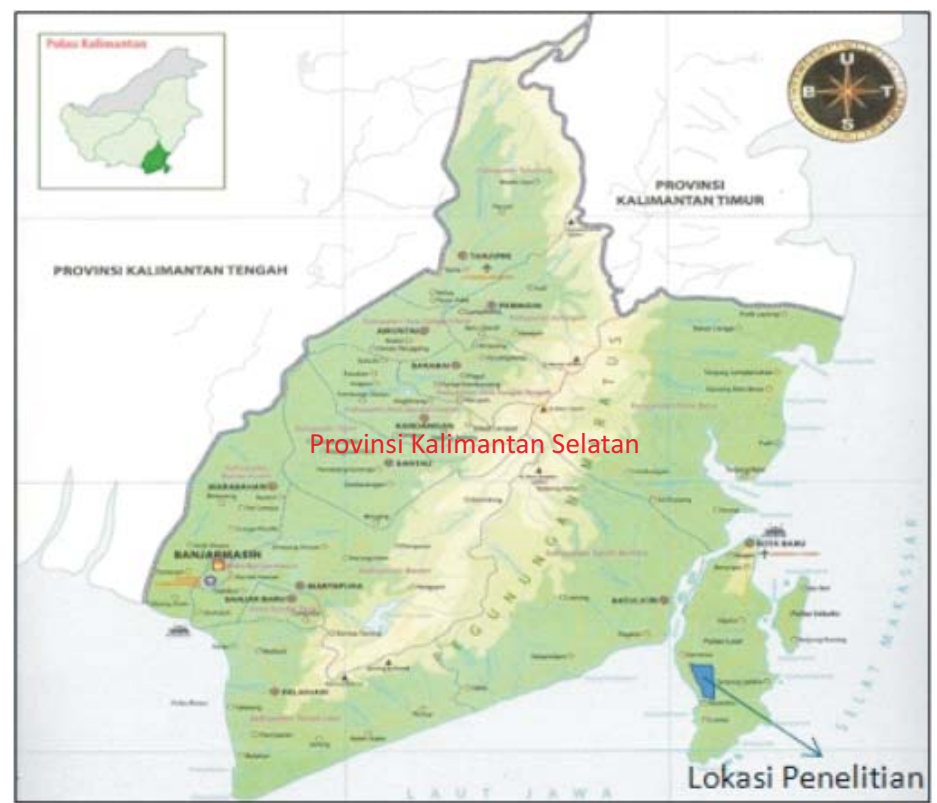

Sumber (Source) : www.banjarmasin.bpk.go.id

Gambar (Figure) 1. Lokasi penelitian (Site of study)

\section{B. Pengukuran Karakteristik Tegakan}

Karakteristik tegakan yang diukur antara lain: umur tanaman, tinggi dan diameter (ratarata maksimum dan minimum) dan kerapatan tanaman. Karakteristik tegakan yang diukur tercantum pada Tabel 1. Dari hasi pengukuran lapangan diketahui bahwa pada umur yang lebih tua, daya hidup tanaman cenderung mengalami penurunan. Hal ini akan berpengaruh terhadap

Tabel (Table) 1. Karakteristik tegakan di lokasi penelitian (Stand characteristic at study sites)

\begin{tabular}{|l|c|c|c|c|c|}
\hline \multicolumn{1}{|c|}{ Parameter } & Umur (Age) & Maximum & Minimum & $\begin{array}{c}\text { Rataan } \\
\text { (Average) }\end{array}$ & $\begin{array}{c}\text { Standar Deviasi } \\
\text { (Standard Deviation) }\end{array}$ \\
\hline Daya & 1 & 92,4 & 76,0 & 82,9 & 6,2 \\
hidup (\%) & 2 & 94,8 & 55,2 & 76,0 & 10,1 \\
(Survival rate\%) & 3 & 75,5 & 34,4 & 54,5 & 11,2 \\
& 4 & 63,9 & 38,9 & 49,2 & 7,5 \\
& 5 & 47,9 & 31,9 & 38,9 & 4,8 \\
& 6 & 61,8 & 44,4 & 51,9 & 5,3 \\
\hline Diameter & 1 & 8,9 & 1,6 & 3,4 & 1,14 \\
(cm) & 2 & 13,4 & 3,5 & 6,4 & 1,95 \\
& 3 & 18,2 & 4,5 & 10,1 & 1,67 \\
& 4 & 31,5 & 5,9 & 16,3 & 3,76 \\
& 5 & 29,6 & 5,1 & 17,8 & 4,59 \\
Tinggi (Height) & 6 & 31,2 & 6,4 & 19,0 & 4,32 \\
(m) & 1 & 5,35 & 3,12 & 3,61 & 0,829 \\
& 2 & 8,10 & 6,00 & 6,10 & 0,860 \\
& 3 & 12,00 & 6,60 & 9,33 & 1,353 \\
& 4 & 27,30 & 13,60 & 20,40 & 2,087 \\
\hline Kerapatan & 5 & 27,00 & 15,00 & 20,02 & 2,787 \\
tegakan & 29,00 & 18,50 & 24,89 & 1,750 \\
(pohon/ha) & 1 & 694 & 823 & 114,8 \\
(Stand density & 2 & 1.003 & 535 & 881 & 306,1 \\
(trees/ha)) & 3 & 989 & 386 & 599 & 168,1 \\
& 4 & 684 & 234 & 526 & 92,5 \\
\hline
\end{tabular}

Sumber (Source): Hasil pengukuran plot-plot penelitian (Result of study plot measurenment) 
kerapatan tanaman tersebut. Pada umur 5 tahun daya hidup tanaman merupakan titik terendah yang mencapai $31 \%$. Kematian tanaman tersebut disebabkan oleh tingginya intensitas serangan penyakit penggerek tanaman dan rebahnya tanaman akibat angin. Hal ini ditandai dengan patahnya batang-batang tanaman $A$. mangium. Berdasarkan informasi dari pengelola HTI, intensitas serangan hama meningkat terutama pada rotasi kedua. Hal ini menyebabkan kerapatan pada umur 6 tahun lebih tinggi daripada kerapatan tanaman umur 3 tahun sampai dengan 5 tahun.

\section{Metode Penelitian}

\section{Inventarisasi persediaan karbon}

Pengukuran persediaan karbon dilakukan dengan menggunakan metode sampling dengan variasi plot pengukuran untuk mengetahui persediaan karbon biomassa hidup (pohon: above dan below ground-biomass). Penelitian ini menggunakan ukuran plot $50 \mathrm{~m}$ x $20 \mathrm{~m}(0,1 \mathrm{Ha})$. Data inventarisasi yang kemudian digunakan dalam membangun model hubungan dengan citra Alos Palsar.

Perhitungan intensitas sampling didasarkan pada besarnya koefisien variasi hasil survey pendahuluan yang telah dilakukan. Survey pendahuluan dilakukan pada tegakan A. mangium umur 4 tahun (luas $914 \mathrm{Ha}$ ). Hasil survey ini menghasilkan CV sebesar 18,1 \% (Lampiran 1). Koefisien variasi ini dirumuskan sebagai berikut:

$C V=\frac{S y}{\bar{y}} \times 100 \%$

Keterangan(Remarks): CV: Koefisien variasi (\%); Sy: Simpangan baku rata-rata; $\bar{y}$ : rata- rata luas bidang dasar pada masingmasing plot survey pendahuluan $\left(\mathrm{m}^{2}\right)$

Dengan menggunakan asumsi bahwa variasi tegakan umur 4 tahun mewakili kondisi seluruh tegakan A. mangium maka dapat ditentukan jumlah keseluruhan plot contoh berdasarkan hasil survey pendahuluan. Penentuan plot berdasarkan nilai koefisien variasi dirumuskan sebagai berikut: (Shiver and Borders 1996)

$n=\frac{4 N(C V)^{2}}{(A E)^{2} N+4(C V)^{2}}$

Keterangan (Remarks): $n=$ jumlah PU ukuran tertentu; $C V=$ koefesien variasi; $A E=\mathrm{ke}-$ salahan sampling maksimum yang diijinkan (5\%); N: Jumlah total plot populasi.
Penentuan sampel sebanyak 69 plot (ukuran plot 0,1 ha atau 6,9 Ha) untuk keseluruhan areal penelitian. Banyaknya plot tersebut dijadikan dasar dalam menentukan banyaknya plot pada masing-masing strata (umur). Pengukuran persediaan karbon ini menggunakan double sampling dengan stratifikasi karena ukuran populasi yang besar dan tersebar dalam beberapa umur. Penentuan banyaknya plot pada masingmasing umur dirumuskan sebagai berikut:

$n_{h}=\frac{L_{h}}{L_{N}} \times n=P_{h} \times n$

Keterangan (Remarks): $\mathrm{n}_{\mathrm{h}}$ : banyaknya plot pada masing-masing umur; $\mathrm{L}_{\mathrm{h}}$ : Luas masingmasing umur; $\mathrm{L}_{\mathrm{N}}$ : Luas seluruh populasi; $\mathrm{n}$ : banyaknya plot total

$\bar{y}_{d s s}=\sum_{h=1}^{L} \frac{\hat{N}_{h} \bar{y}_{h}}{N}=\sum_{h=1}^{L} P_{h} \bar{y}_{h}$

Keterangan (Remarks): $\bar{y}_{d s \dot{s}}:$ Rata-rata keseluruhan dari double sampling dengan stratifikasi; $\mathrm{Ph}$ : proporsi masing-masing umur; $\hat{N}_{h}$ : populasi/luas masing-masing umur; $\bar{y}_{h}$ : Rata-rata masing-masing strata (umur).

Pendugaan persediaan karbon permukaan dan total dengan menggunakan persamaan alometrik hubungan dimensi dengan simpanan karbon. Model alometrik tersebut yakni simpanan karbon permukaan:

In permukaan $=-3,85+2,79 \ln$ Diameter ............(5) (Qirom 2011)

In total $=-3,62+2,74 \ln$ Diameter

(6) (Qirom 2011).

Dugaan persediaan karbon permukaan dan total dengan menggunakan rumus:

$\hat{T}_{d s s}=N \bar{y}_{d s}$

$S_{\bar{y}_{d s s}^{2}}^{2}=\sum_{h=1}^{L}\left(p_{h}^{2}-\frac{p_{h}}{n}\right) \frac{S_{h}^{2}}{n_{h}}+\frac{1}{n}\left[\left(\sum_{h=1}^{L} p_{h} \bar{y}_{h}\right)^{2}-\left(\bar{y}_{d s s}\right)^{2}\right] \ldots(8)$

$S_{\bar{y}_{d s s}}=\sqrt{S_{\bar{y}_{d s s}}^{2}}$

$S_{\hat{T}_{d s s}}=N S_{\bar{y}_{d s s}}$

$\bar{y}_{d s s} \pm 2 S_{\bar{y}_{d s s}}$

Keterangan (Remarks): $\hat{T}_{d s s}$ total persediaan karbon; $\bar{y}_{d s s}$ : Rata-rata keseluruhan persediaan karbon dari double sampling dengan stratifikasi; $\mathrm{P}_{\mathrm{h}}$ : proporsi masing-masing umur; $\hat{N}_{h}$ : populasi/luas masing-masing umur; $\bar{y}_{h}$ : Rata-rata masing-masing strata (umur); $S_{\overline{\bar{y}} d \mathrm{ss}}$ : simpangan baku dari metode double sampling. 
Tabel2. Sebaran plot pengukuran masing-masing umur untuk penyusunan model penduga simpanan karbon (Distribution of measurenment plot on each age class for carbon storage model contruction)

\begin{tabular}{|c|c|c|c|}
\hline $\begin{array}{c}\text { Umur } \\
(\text { Age })\end{array}$ & $\begin{array}{c}\text { Jumlah Plot } \\
\text { (Number of Plot) }\end{array}$ & $\begin{array}{c}\text { Umur } \\
(\text { Age })\end{array}$ & $\begin{array}{c}\text { Jumlah Plot } \\
\text { (Number of Plot) }\end{array}$ \\
\hline 1 tahun & 5 plot & 6 tahun & 10 plot \\
2 tahun & 14 plot & 7 tahun & 12 plot \\
3 tahun & 21 plot & 8 tahun & 13 plot \\
4 tahun & 11 plot & 9 tahun & 4 plot \\
5 tahun & 8 plot & 10 tahun & 9 plot \\
\hline
\end{tabular}

Keterangan (Remarks): Umur 7- 10 tahun tidak memungkinkan untuk dibuat plot penelitian (Age 7-10 years is not possible to compose of research plot); 8-10 ditebang untuk RKT 2010: 8-10 was harvested); 7 tahun terserang hama penyakit yang sangat parah dan terbakar (7 years was attacked by pest and disease and burned)

Plot inventarisasi ini diambil pada beberapa tingkat umur. Hasil inventarisasi ini digunakan dalam penyusunan dan validasi model pendugaan karbon berdasarkan hubungan antara persediaan karbon dan parameter spektral (nilai backscatter). Sebaran banyaknya plot pada masing-masing umur untuk pembuatan model simpanan karbon pada Tabel 2.

\section{Aplikasi penginderaan jarak jauh dalam pendugaan simpanan karbon}

Pendugaan simpanan karbon dengan aplikasi teknologi penginderaan jarak jauh merupakan analisis lanjutan setelah citra tersebut dilakukan sejumlah proses analisis citra. Pada dasarnya dalam analisis citra ini terdapat beberapa tahapan yakni: koreksi geometrik dan radiometrik, dan ekstraksi karakteristik spasial. Citra yang digunakan telah dikoreksi baik geometrik dan radiometrik sehingga proses selanjutnya yakni ekstraksi karakteristik spasial.

Ekstraksi karakteristik spasial dilakukan pada setiap plot pengukuran. Karakteristik spasial berupa nilai digital number pada masingmasing layer citra. Nilai Backscatter masingmasing layer digunakan dalam pembuatan model. Hasil ekstraksi ini digunakan sebagai input dalam analisis statistik. Citra radar hanya memiliki dua band yakni layer $\mathrm{HV}$ dan $\mathrm{HH}$ sehingga untuk interpretasi perlu menambahkan satu band sintetis pada citra Alos Palsar bandband sintetis yang ditambahkan yakni :

$$
\text { Ratio }=\frac{H H}{H V}
$$

Parameter-parameter di atas digunakan dalam penyusunan model penduga persediaan karbon. Model yang akan digunakan yakni

Model linear: $Y=b_{0}+b_{1} X_{1}+b_{2} X_{2}+\ldots \ldots .+b_{i} X_{i}$

Model power (kuadratif): $Y=b_{0} X_{1}^{b_{1}} X_{2}^{b_{2}} \ldots \ldots . X_{i}^{b_{i}}$
Model eksponensial: $Y=e^{b_{0}+b_{1} X_{1}+b_{2} X_{2}+\ldots \ldots+b_{i} X_{i}}$

keterangan: $b_{0}, b_{1}, b_{2} \ldots b_{i}:$ parameter regresi; $X_{1}$, $\mathrm{X}_{2} \ldots \mathrm{X}_{\mathrm{i}}$ : nilai backscatter

Model terbaik dipilih dari seluruh model yang telah disusun berdasarkan persamaan 13 15. Model terbaik dipilih berdasarkan beberapa kriteria pemilihan model terbaik yakni koefisien determinasi maksimum ( $\mathrm{R}^{2}$ maksimum), simpangan baku minimum (s), dan koefisien determinasi terkoreksi maksimum ( $\mathrm{R}_{\text {adj }}^{2}$ maksimum) (Draper dan Smith, 1992) dan PRESS serta analisis sisaan. Model terbaik digunakan dalam menduga persediaan karbon secara keseluruhan. Model terbaik ini harus dilakukan validasi model. Validasi ini berguna untuk mendapatkan model yang mempunyai tingkat akurasi tinggi dalam menduga simpanan karbon tegakan A mangium. Validasi model ini menggunakan uji-t.

Berdasarkan uji t, model penduga simpanan karbon dapat digunakan, jika $\mathrm{t}_{\text {hitung }}<\mathrm{t}_{\text {tabel }}$. Hal ini berarti hasil dugaan simpanan karbon tidak berbeda dengan hasil pengukuran simpanan karbon di lapangan. Namun, apabila hasil uji berbeda nyata $\left(t_{\text {hitung }}>t_{\text {tabel }}\right)$ maka model penduga simpanan karbon tersebut tidak dapat digunakan menduga simpanan karbon tegakan A. mangium.

\section{HASIL DAN PEMBAHASAN}

\section{A. Potensi Simpanan Karbon pada Tegakan A. mangiun}

\section{Potensi simpanan karbon per ha}

Potensi persediaan karbon permukaan dan total dihitung berdasarkan model alometrik simpanan karbon. Hasil persediaan karbon terbesar pada umur 6 tahun (Tabel 3). Hal ini me- 
nunjukkan persediaan karbon akan bertambah besar seiring dengan pertambahan umur (dimensi tanaman semakin besar). Fakta yang berbeda ditunjukkan oleh umur 5 tahun dengan persediaan karbon lebih kecil daripada umur 4 tahun. Hal ini karena tingkat kematian pada umur 5 tahun sangat besar yang ditunjukkan oleh daya hidup yang rendah sebesar 31,9\% (Tabel 1). Hal ini diakibatkan tingginya serangan hama penggerek batang pada umur 5 tahun. Serangan hama ini terjadi pada keseluruhan tanaman pada umur tersebut.

Potensi persediaan karbon yang dihasilkan penelitian ini lebih tinggi jika dibandingkan dengan penelitian yang lain untuk jenis yang sama. Dahlan et al. (2005) mendapatkan rata- rata persediaan karbon pada umur 6 tahun sebesar 25,63 ton/ha. Jika dibandingkan dengan jenis yang berbeda (jenis Jati) hasil penelitian ini lebih rendah (Kraenzel et al., 2003). Besarnya potensi karbon pada beberapa jenis dan tempat tumbuh mempunyai potensi yang berbeda-beda (Tabel 4).

\section{Potensi persediaan karbon di lokasi peneli- tian}

Lokasi penelitian di PT. Inhutani II, Sub Unit Semaras Kalimantan Selatan ini didominasi oleh tanaman muda dengan luasan yang sangat besar. Hasil perhitungan potensi karbon untuk karbon permukaan mempunyai rata-rata 39,06 ton/ha. Selang dugaan potensi simpanan karbon

Tabel (Table) 3. Persediaan karbon permukaan dan total pada beberapa umur (Above ground and total carbon stock on various age)

\begin{tabular}{|l|c|c|c|c|c|c|c|c|}
\hline \multirow{2}{*}{$\begin{array}{c}\text { Umur(Age) } \\
\text { Tahun } \\
\text { Year })\end{array}$} & \multicolumn{3}{|c|}{$\begin{array}{c}\text { Persediaan Karbon Permukaan } \\
\text { (Above Ground Carbon Stock) (ton/ha) }\end{array}$} & \multicolumn{4}{c|}{$\begin{array}{c}\text { Persediaan Karbon Total } \\
\text { (Total Carbon Stock) (ton/ha) }\end{array}$} \\
\cline { 2 - 9 } & Min & Max & Rataan & Stdev & Min & Max & Rataan & Stdev \\
\hline 1 & 0,67 & 1,33 & 1,01 & 0,293 & 0,79 & 1,56 & 1,19 & 0,34 \\
2 & 2,44 & 8,28 & 5,02 & 1,736 & 2,84 & 9,43 & 5,76 & 1,97 \\
3 & 4,83 & 17,87 & 10,70 & 3,770 & 5,50 & 20,19 & 12,12 & 4,24 \\
4 & 32,96 & 56,53 & 41,77 & 7,898 & 36,79 & 62,36 & 46,33 & 8,61 \\
5 & 24,07 & 39,15 & 34,63 & 4,748 & 26,60 & 43,27 & 38,26 & 5,24 \\
6 & 49,88 & 140,10 & 77,76 & 29,566 & 55,02 & 154,56 & 85,78 & 32,65 \\
\hline
\end{tabular}

Keterangan (Remarks): Min: nilai minimum (Minimum value); Max: nilai maximum (Maximum value); Stdev:standar deviasi (standard deviation)

Tabel(Table) 4. Potensi simpanan karbon pada beberapa jenis dan lokasi yang berbeda (Carbon stock potensial on varied of species and site)

\begin{tabular}{|c|c|c|c|c|}
\hline $\begin{array}{l}\text { Jenis } \\
\text { (Species) }\end{array}$ & $\begin{array}{l}\text { Lokasi } \\
\text { (Site) }\end{array}$ & $\begin{array}{l}\text { Umur (Age) } \\
\text { Tahun (Year) }\end{array}$ & $\begin{array}{l}\text { Potensi Karbon } \\
\text { (Carbon Stock) } \\
(\text { ton } / \mathrm{ha})\end{array}$ & $\begin{array}{l}\text { Sumber } \\
\text { (Source) }\end{array}$ \\
\hline A. mangium & Kalsel & $1-6$ & 43,2 & Hasil penelitian \\
\hline A. mangium & $\begin{array}{l}\text { BPKH Parung } \\
\text { Panjang }\end{array}$ & $1-10$ & $53,89 *$ & Dahlan et al. (2005) \\
\hline A. mangium & $\begin{array}{l}\text { Musi Hutan Persada } \\
\text { Palembang }\end{array}$ & 9 & $189,5^{*}$ & $\begin{array}{l}\text { Hardiyanto et al. } \\
(2000)\end{array}$ \\
\hline A. mangium & $\begin{array}{l}\text { BKPH Maribaya dan } \\
\text { Tenjo, Bogor }\end{array}$ & 8 & $64,02 *$ & Heriansyah (2005) \\
\hline Pinus mercusii & BKPH Leuwiliang & 11 & $126,55^{*}$ & Heriansyah (2005) \\
\hline Tectona Grandis & Panama & 20 & 130 & Kraenzel et al. (2003) \\
\hline Hevea braziliensis & Brasil & $14-25$ & 41,7 & Wauters et al. (2008) \\
\hline Hevea brasiliensis & Ghana & $2-14$ & 76,3 & Wauters et al. (2008) \\
\hline Bamboo spp. & India & - & 61,07 & Nath et al. (2009) \\
\hline $\begin{array}{l}\text { Areal bera dan } \\
\text { pertanian }\end{array}$ & Malaysia & 6 & $47,0^{*}$ & Jepsen (2006) \\
\hline
\end{tabular}

Ketarangan (Remarks):*: Simpanan karbon dalam bentuk biomasa (Carbon stock in the form biomass) 
permukaan yakni 32,03 - 46,10 ton/ha. Pendugaan simpanan karbon permukaan seluruh lokasi penelitian yakni 112.549,75 ton dengan pendugaan selang pada selang kepercayaan $95 \%$ adalah $92.280,98$ - 132.828,51 ton dengan luas areal 2.881,1 hektar.

Pendugaan simpanan karbon juga dilakukan dengan menduga simpanan karbon total termasuk akar. Hasil dugaan simpanan karbon total menghasilkan rata-rata simpanan karbon total untuk seluruh areal lokasi penelitian yakni 43,24 ton/ha dengan selang dugaannya 35,48 - 51,01 ton/ha (selang kepercayaan 95\%). Penduga-an simpanan karbon total seluruh lokasi peneliti-an menghasilkan dugaan sebesar 124.591,21 ton dengan selang dugaannya 102.208,56 - 146.973,86 ton pada selang kepercayaan $95 \%$.

Hasil dugaan simpanan karbon permukaan ini jauh lebih besar dibandingkan dengan hasil dugaan simpanan karbon permukaan yang dilakukan oleh Dahlan et al. (2005). Dahlan et al. (2005) menduga simpanan karbon jenis $A$. mangium pada areal yang luasnya 3.398,04 Ha. Hasil dugaan mencapai 56.139 ton karbon pada luasan tersebut (Dahlan et al., 2005). Perbedaan ini dapat disebabkan oleh beberapa hal yakni terkait dengan tempat tumbuhnya dan jenis $A$. mangium yang ditanam (seperti asal benih: keturunan F-1, provenan atau klon).

\section{B. Aplikasi Citra Alos Palsar untuk Penduga- an simpanan karbon}

Citra Alos Palsar yang digunakan untuk pendugaan simpanan karbon memiliki perbedaan terkait dengan waktu peliputan (2009) dan inventarisasi simpanan karbon (2010). Perbedaan waktu ini tentunya akan mengakibatkan perbedaan dimensi tanaman (diameter) A. mangium hasil inventarisasi tahun 2009 dan tahun 2010. Hal ini akan menyebabkan perbedaan simpanan karbon masing-masing umur pada periode tersebut. Perbedaan diameter tersebut harus dilakukan koreksi dimensi tanaman yakni selisih antara pengukuran tahun 2010 dengan tahun $2009\left(\varnothing_{2009}<\varnothing_{2010}\right)$.

Idealnya koreksi tersebut dilakukan pada setiap pohon pada setiap plot inventarisasi sehingga selisih diameter pohon pada periode tersebut diketahui. Namun, data inventarisasi pohon pada tahun 2009 tidak tersedia sehingga koreksi dilakukan secara sistematis artinya setiap ukuran dimensi per umur pada tahun 2010 dikurangi dengan besaran nilai dimensi tahun 2009 (pada citra) sehingga koreksi terhadap diameter (simpanan karbon) tidak mempengaruhi bentuk hubungan antara simpanan karbon dengan nilai polarisasi citra Alos Palsar.

\section{Pola hubungan polarisasi Horizontal- Horizontal (HH) dan Horizontal-Vertikal (HV)}

Tahap awal dalam menduga simpanan karbon dengan menggunakan citra ini yakni membentuk hubungan antara karakteristik tegakan (besarnya simpanan karbon hasil inventarisasi) dengan karakteristik yang ter-kandung dalam citra (nilai backscatter). Hasil ekstraksi citra didapatkan besarnya nilai polari-sasi oleh sensor $\mathrm{HH}$ dan $\mathrm{HV}$ yang ditunjukkan oleh Tabel 5.

Secara umum, nilai HH lebih besar dibandingkan dengan nilai HV dengan selang yang relatif sempit. Nilai-nilai $\mathrm{HH}$ dan $\mathrm{HV}$ memiliki kecenderungan homogen yakni mempunyai koefisien variasi yang kecil kurang dari $10 \%$. Bentuk hubungan antara simpanan karbon dengan polarisasi $\mathrm{HH}$ dan $\mathrm{HV}$ hampir

Tabel(Table) 5. Hasil ekstraksi nilai polarisasi HH dan HV (Extraction of HH and HV polaroization value)

\begin{tabular}{|c|c|c|c|c|c|c|c|c|c|c|}
\hline \multirow{2}{*}{$\begin{array}{c}\text { Umur/Age } \\
\text { (Tahun/Year }\end{array}$} & \multicolumn{5}{|c|}{ HH } & \multicolumn{3}{c|}{ HV } \\
\hline 1 & $-7,03$ & $-5,77$ & $-6,31$ & 0,46 & $-7,27$ & $-14,12$ & $-13,24$ & $-13,54$ & 0,40 & $-2,98$ \\
2 & $-8,86$ & $-7,53$ & $-8,32$ & 0,49 & $-5,91$ & $-16,83$ & $-14,35$ & $-15,90$ & 0,76 & $-4,80$ \\
3 & $-7,92$ & $-7,11$ & $-7,67$ & 0,22 & $-2,81$ & $-14,57$ & $-13,23$ & $-14,00$ & 0,44 & $-3,16$ \\
4 & $-7,69$ & $-6,99$ & $-7,45$ & 0,22 & $-2,89$ & $-13,49$ & $-12,89$ & $-13,28$ & 0,19 & $-1,43$ \\
5 & $-7,03$ & $-6,51$ & $-6,69$ & 0,19 & $-2,85$ & $-13,21$ & $-12,98$ & $-13,07$ & 0,08 & $-0,59$ \\
6 & $-7,74$ & $-7,27$ & $-7,50$ & 0,20 & $-2,66$ & $-13,99$ & $-12,91$ & $-13,32$ & 0,40 & $-2,97$ \\
\hline
\end{tabular}

Keterangan (Remarks): Min: nilai minimum (Minimum value); Max: nilai maksimum (Maximum value); Stdev: Standar deviasi (Standard deviation); CV: Koefisien variasi (\%) (Coefficient of variation) 
sama yakni pada suatu titik tertentu penambahan simpanan karbon tidak merubah nilai $\mathrm{HH}$ dan $\mathrm{HV}$ (Gambar 2 dan 3).

Secara umum, pola hubungan polarisasi $\mathrm{HH}$ dengan simpanan karbon menunjukkan keeratan hubungan yang positif artinya kenaikan simpanan karbon diikuti oleh kenaikan polarisasi HH. Pada umur 1 tahun, simpanan karbon yang kecil mempunyai polarisasi $\mathrm{HH}$ yang besar. Kondisi ini diduga disebabkan oleh adanya pengaruh kerapatan cabang dan ranting. Umumnya tegakan umur 1 tahun adalah tegakan yang tidak teratur jarak tanamnya. Ketidakteraturan ini disebabkan oleh tanaman yang tumbuh tidak pada jalur tanamnya (pertumbuhan semai yang tidak terkendali). Kondisi lokasi penelitian terutama umur 1 tahun memasuki rotasi kedua. Pada rotasi kedua, umumnya banyak semai yang tumbuh secara mengelompok dan menyebabkan kerapatan cabang menjadi sangat tinggi. Selain itu, kondisi tersebut diduga disebabkan oleh kondisi pada saat perekaman berbeda dengan kondisi inventarisasi. Pada saat perekaman, kemungkinan tegakan tersebut belum ditebang sehingga kondisi tersebut menyebabkan polarisasi $\mathrm{HH}$ menjadi tinggi.

Pada titik tertentu, pola polarisasi $\mathrm{HH}$ ini memiliki kecederungan tetap. Kondisi ini terjadi pada tegakan umur 6 tahun dengan simpanan karbon lebih dari 60 ton/ha atau setara 120 ton/ha biomassa. Hal ini menunjukkan penambahan simpan- an karbon lebih dari 60 ton/ha tidak akan mempengaruhi polarisasi $\mathrm{HH}$. Kondisi ini biasa dikenal saturasi. Titik saturasi ini tidak jauh berbeda dengan yang dihasilkan Rauste (2006) pada hutan sekunder di Finlandia.

Pola hubungan antara simpanan karbon dengan polarisasi HV mempunyai kesamaan pola hubungan polarisasi HH (Gambar 2). Nilai polarisasi $\mathrm{HV}$ akan meningkat sebanding dengan peningkatan simpanan karbon. Namun kondisi sebaliknya terjadi pada umur 1 tahun, nilai polarisasi HV lebih tinggi dibandingkan umur yang lain (2, 3, dan 5 tahun). Hal ini kemungkinan disebabkan oleh kondisi pada saat perekaman oleh citra berbeda dengan kondisi inventarisasi. Pada saat perekaman sebenarnya obyek mempunyai biomassa yang tinggi karena tegakan tua dan tegakan tersebut telah ditebang setelah perekaman terjadi. Hal ini berakibat pada tingginya nilai HV yang terekam oleh citra dan rendahnya biomassa hasil inventarisasi.

Pola hubungan antara polarisasi HV dengan simpanan karbon menunjukkan kejenuhan atau titik saturasi pada umur 6 tahun dengan simpanan karbon lebih dari 60 ton/ha atau setara 120 ton/ha biomassa. Titik saturasi yang didapatkan dalam penelitian berbeda yang didapatkan oleh Rauste (2006). Titik saturasi tercapai pada biomassa 150 ton/ha (Rauste 2006). Penelitian ini dilakukan di hutan sekunder Finlandia.

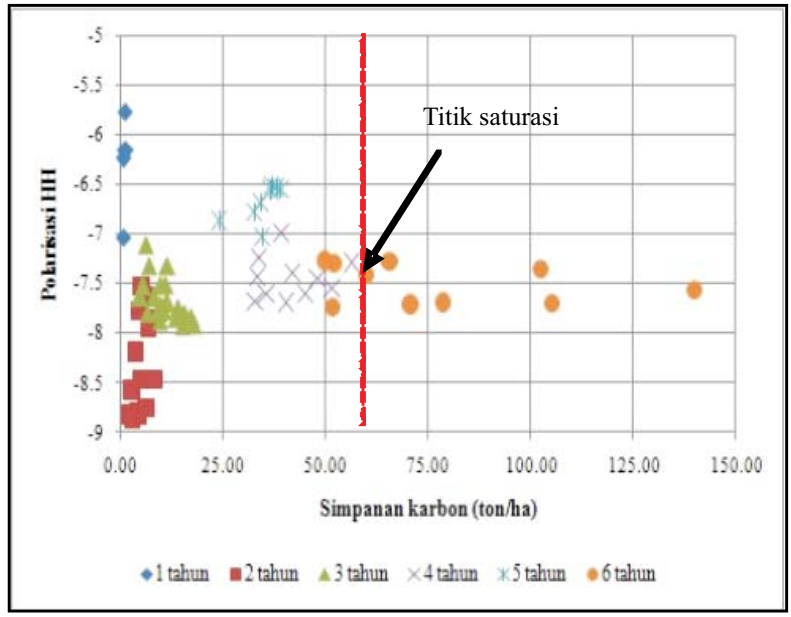

Gambar(Figure) 2. Pola polarisasi HH (HHpolarization trend)

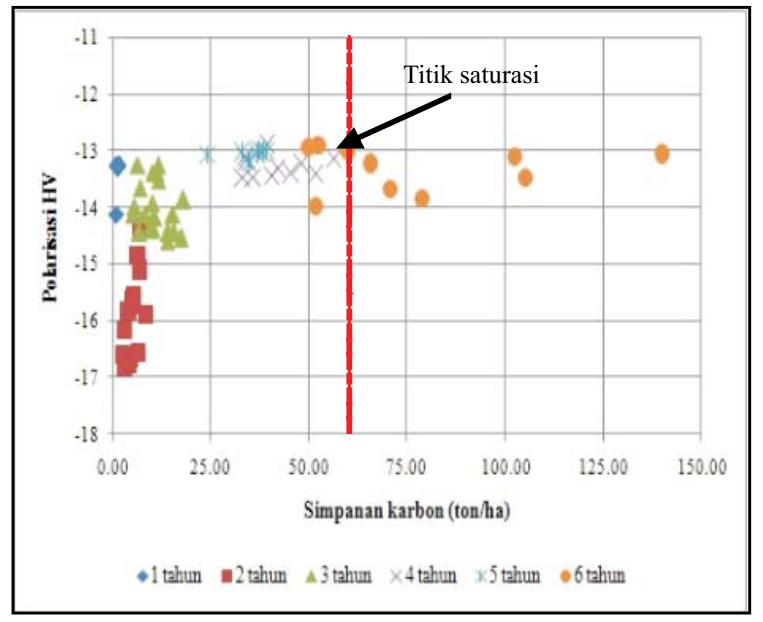

Gambar(Figure) 3. Pola polarisasi HV (HVpolarization trend) 


\section{Model penduga simpanan karbon berdasar- kan polarisasi $\mathrm{HH}$ dan $\mathrm{HV}$}

Penyusunan model ini didasarkan pada pola hubungan antara simpanan karbon hasil inventarisasi dengan polarisasi $\mathrm{HH}$ dan $\mathrm{HV}$ hasil ekstraksi citra. Model yang disusun merupakan gabungan dari keseluruhan umur di lokasi penelitian. Hal ini didasarkan pada scatter plot antara simpanan karbon dan polarisasi $\mathrm{HH}$ dan HV (Gambar 2 dan 3). Berdasarkan Gambar 2 dan 3 diketahui bahwa data-data yang ada cenderung mengelompok dan tidak ada yang terpisah sehingga penggunaan data gabungan dilakukan dalam penyusunan model penduga simpanan karbon berdasarkan polarisasi $\mathrm{HH}$ dan HV.

Hasil analisis regresi menunjukkan bahwa penggunaan polarisasi HV dan kombinasinya sebagai variabel bebas memiliki koefisien determinasi $\left(\mathrm{R}^{2}\right)$ yang cenderung lebih tinggi dibandingkan polarisasi HH sebagai variabel bebas dalam menduga simpanan karbon (Tabel 6). Hasil ini tidak jauh berbeda dengan hasil penelitian Nurhayati (2010) dan Pandey et al. (2010) yang menyatakan polarisasi HV lebih sensitif terhadap biomassa.
Secara umum, model yang disusun mempunyai variabel bebas yang berpengaruh terhadap variabel tidak bebasnya. Hal ini ditunjukkan oleh $\mathrm{F}_{\text {hitung }}>\mathrm{F}_{\text {tabel }}$ artinya secara bersama-sama variabel bebasnya berpengaruh terhadap variabel tidak bebas kecuali model 1 dan 2 (Tabel 6).

Calon model terbaik ditentukan berdasarkan kriteria pemilihan model terbaik $\left(\mathrm{R}_{\text {adj; }}^{2}\right.$; simpangan baku, dan PRESS). Hasil skoring menunjukkan model 11 adalah model terbaik. Model ini mempunyai $\mathrm{R}^{2}$ sebesar $40,9 \%$ artinya 40,9 \% variasi dari simpanan karbon dapat dijelaskan oleh variasi polarisasi $\mathrm{HV}$ dan $\mathrm{HH}$ sebagai variabel selebihnya dipengaruhi oleh faktor lain. Jika dilihat koefisien determinasinya model ini mempunyai koefisien determinasi yang kecil $<50 \%$ tetapi model ini dapat digunakan karena semua variabel bebasnya berpengaruh terhadap variabel tidak bebasnya. Hasil penelitian ini berbeda dengan hasil penelitian Pandey et al. (2010) dan Nurhayati (2010). model alometrik terbaik untuk menduga simpanan karbon menggunakan polarisasi HV sebagai peubah bebas dari model tersebut (Pandey et al., 2010; Nurhayati, 2010).

Tabel (Table) 6. Model penduga simpanan karbon jenis A. mangium berdasarkan polarisasi HH dan HV (Carbon storage model of $\underline{A}$. mangium based on HH and HV polarization)

\begin{tabular}{|l|l|c|c|c|c|c|c|}
\hline $\begin{array}{c}\text { No } \\
(\text { No })\end{array}$ & \multicolumn{1}{|c|}{$\begin{array}{c}\text { Model Regresi } \\
(\text { Regression Model })\end{array}$} & $\mathrm{R}^{2}(\%)$ & $\mathrm{R}^{2}$ adj(\%) & $\mathrm{s}$ & PRESS & $\begin{array}{r}\mathrm{F}_{\text {hitung }} \\
\left(F_{\text {calc }}\right)\end{array}$ & $P_{\text {value }}$ \\
\hline 1. & $\mathrm{Cs}=78,4+6,92 \mathrm{HH}$ & 2,5 & 1,1 & 27,84 & 54604,1 & 1,75 & 0,190 \\
2. & $\mathrm{Cs}=56,5-0,529 \mathrm{HH}^{2}$ & 3,3 & 1,9 & 27,72 & 54022,8 & 2,32 & 0,132 \\
3. & $\mathrm{Cs}=205+12,7 \mathrm{HV}$ & 25,2 & 24,1 & 24,39 & 41740,8 & 22,56 & 0,000 \\
4. & $\mathrm{Cs}=111-0,426 \mathrm{HV}$ & 24,3 & 23,2 & 24,54 & 42232,8 & 21,49 & 0,000 \\
5. & $\mathrm{Cs}=177-27,4 \mathrm{HH}+25,5 \mathrm{HV}^{2}$ & 40,2 & 38,4 & 21,97 & 34263,8 & 22,20 & 0,000 \\
6. & $\mathrm{Cs}=-784-226 \mathrm{HH}-15,6 \mathrm{HH}^{2}$ & 15,3 & 12,7 & 26,15 & 47455,9 & 5,96 & 0,004 \\
7. & $\mathrm{Cs}=1414+179 \mathrm{HV}+5,65 \mathrm{HV}^{2}$ & 30,9 & 28,8 & 23,62 & 38969,4 & 14,76 & 0,000 \\
8. & $\mathrm{Cs}=61,0+0,0428 \mathrm{HH}^{2} \mathrm{HV}$ & 9,3 & 8,0 & 26,85 & 50403,4 & 6,88 & 0,011 \\
9. & $\mathrm{Cs}=71,7+0,0301 \mathrm{HV}^{2} \mathrm{HH}$ & 16,1 & 14,9 & 25,83 & 46600,8 & 12,86 & 0,001 \\
10. & $\mathrm{Cs}=-5,4-0,838 \mathrm{HV}^{2}-26,3 \mathrm{HH}$ & 38,2 & 36,3 & 22,34 & 35389,5 & 20,38 & 0,000 \\
$\mathbf{1 1 .}$ & $\mathrm{Cs}=\mathbf{2 9 2}+\mathbf{2 , 0 0} \mathbf{H H}+\mathbf{2 7 , 1} \mathbf{H V}$ & $\mathbf{4 0 , 9}$ & $\mathbf{3 9 , 1}$ & $\mathbf{2 1 , 8 4}$ & $\mathbf{3 3 9 3 4 , 4}$ & $\mathbf{2 2 , 8 4}$ & $\mathbf{0 , 0 0 0}$ \\
12. & $\mathrm{Cs}=193,485(\mathrm{Abs}(\mathrm{HH}))^{-0,991}$ & 1,1 & 0,0 & 28,04 & 52686,2 & 30,71 & 0,000 \\
13. & $\mathrm{Cs}=7 * 10^{9}(\mathrm{Abs}(\mathrm{HV}))^{-7,366}$ & 28,1 & 27,0 & 23,92 & $1,17 \mathrm{E}+09$ & 54,78 & 0,000 \\
14. & $\mathrm{Cs}=9,076 \mathrm{e}^{0,162 \mathrm{HH}}$ & 0,16 & 0,13 & 27,97 & 91574,6 & 31,02 & 0,000 \\
15. & $\mathrm{Cs}=5385065 \mathrm{e}^{0,895 \mathrm{HV}}$ & 30,9 & 30,0 & 23,44 & 36810,38 & 58,40 & 0,000 \\
16. & $\mathrm{Cs}=7567568 \mathrm{e}^{1,735 \mathrm{HH}-1,486 \mathrm{HV}}$ & 53,6 & 52,1 & 19,36 & $1,7 \mathrm{E}+11$ & 67,77 & 0,000 \\
17. & $\mathrm{Cs}=3480,804 \mathrm{e}^{0,229(\mathrm{HH}+\mathrm{HV})}$ & 12,9 & 11,6 & 26,32 & 46410,57 & 39,40 & 0,000 \\
18. & $\mathrm{Cs}=4 * 10^{9}(\mathrm{HH} / \mathrm{HV})^{23,745}$ & 38,4 & 37,5 & 22,14 & $7,82 \mathrm{E}+08$ & 69,52 & 0,000 \\
\hline
\end{tabular}

Keterangan (Remarks): Cs: Simpanan karbon (ton/ha) (Carbon storage) 


\section{Validasi model penduga simpanan karbon terbaik}

Validasi model ini dilakukan sebelum menggunakan model-model yang terpilih. Pada dasarnya validasi dilakukan dengan membandingkan hasil dugaan berdasarkan model terbaik dengan simpanan karbon hasil inventarisasi. Validasi ini sebagai dasar untuk menentukan model yang digunakan untuk pendugaan simpanan karbon berdasarkan polarisasi $\mathrm{HH}$ dan $\mathrm{HV}$. Jika hasil dugaan berbeda dengan simpanan karbon hasil inventarisasi maka model penduga tersebut tidak dapat digunakan untuk menduga simpanan karbon. Uji-t digunakan untuk membandingkan hasil dugaan berdasarkan dengan simpanan karbon aktual (Tabel 7). Model yang digunakan dalam uji validasi ini adalah semua model yang memenuhi kriteria keberartian model kecuali model 1 dan 2.

Sebagian besar, model alometrik yang disusun memiliki kemampuan untuk menduga simpanan karbon yang ditunjukkan oleh $\mathrm{t}_{\text {hitung }}<$ $\mathrm{t}_{\text {tabel }}$. Hasil uji-t menunjukkan semua model linear dapatmenduga dengan baik simpanan karbon sedangkan model non linear tidak dapat digunakan untuk menduga simpanan karbon (model 13, 14, 16, dan 18). Model 16 mempunyai koefisien determinasi yang tinggi (lebih dari 50\%) tetapi model ini mempunyai hasil dugaan yang berbeda dengan simpanan karbon hasil inventarisasi. Pada tahap sebelumnya model yang terpilih adalah model 11. Berdasarkan hasil uji-t (Tabel 7) model ini dapat digunakan dalam menduga simpanan karbon dengan menggunakan polarisasi $\mathrm{HH}$ dan $\mathrm{HV}$ secara bersama-sama.

Model terbaik yang dihasilkan mempunyai $\mathrm{R}^{2}$ lebih besar dibandingkan dengan hasil penelitian Pandey et al. (2010) yang dilakukan pada hutan tanaman jati $\left(\mathrm{R}^{2}=23 \%\right)$ dan hutan campuran $(5 \%)$. Pada tegakan hutan tanaman eukaliptus, hubungan polarisasi HV dengan biomassa eukaliptus memperoleh $\mathrm{R}^{2}=68 \%$ (Pandey et al. 2010). Menurut Pandey et al. (2010) umumnya besarnya koefisien determinasi hubungan antara polarisasi dengan biomassa sangat dipengaruhi tinggi dan rendahnya potensi biomassa di lokasi tersebut. Besarnya koefisien determinasi lebih tinggi pada areal dengan potensi biomassa $<115$ ton/ha (Tabel 8). Koefisien determinasi pada lokasi tersebut mencapai lebih dari $>70 \%$ (Pandey et al., 2010).

Tabel 7. Hasil uji-t terhadap dugaan model alometrik dengan simpanan karbon aktual (Result of t-test for estimation allometric model with actual of carbon storage)

\begin{tabular}{|c|c|c|c|c|c|}
\hline No & Model & $\mathrm{R}^{2}(\%)$ & $t_{\text {hitung }}$ & Sig & $\mathrm{t}_{\text {tabel }(0,025,68)}$ \\
\hline 3. & $\mathrm{Cs}=205+12,7 \mathrm{HV}$ & 25,2 & $-0,172$ & 0,864 & 2,292 \\
\hline 4. & $\mathrm{Cs}=111-0,426 \mathrm{HV}^{2}$ & 24,3 & $-0,109$ & 0,914 & 2,292 \\
\hline 5. & $\mathrm{Cs}=177-27,4 \mathrm{HH}+25,5 \mathrm{HV}$ & 40,2 & 0,299 & 0,766 & 2,292 \\
\hline 6. & $\mathrm{Cs}=-784-226 \mathrm{HH}-15,6 \mathrm{HH}^{2}$ & 15,3 & $-0,172$ & 0,864 & 2,292 \\
\hline 7. & $\mathrm{Cs}=1414+179 \mathrm{HV}+5,65 \mathrm{HV}^{2}$ & 30,9 & 1,707 & 0,092 & 2,292 \\
\hline 8. & $\mathrm{Cs}=61,0+0,0428 \mathrm{HH}^{2} \mathrm{HV}$ & 9,3 & $-0,011$ & 0,991 & 2,292 \\
\hline 9. & $\mathrm{Cs}=71,7+0,0301 \mathrm{HV}^{2} \mathrm{HH}$ & 16,1 & $-0,005$ & 0,996 & 2,292 \\
\hline 10. & $\mathrm{Cs}=-5,4-0,838 \mathrm{HV}^{2}-26,3 \mathrm{HH}$ & 38,2 & $-0,132$ & 0,896 & 2,292 \\
\hline 11. & $\mathrm{Cs}=292+2,00 \mathrm{HH}^{2}+27,1 \mathrm{HV}$ & 40,9 & 0,126 & 0,900 & 2,292 \\
\hline 12. & $\mathrm{Cs}=193,485(\mathrm{Abs}(\mathrm{HH}))^{-0,991}$ & 1,1 & $-0,020$ & 0,984 & 2,292 \\
\hline 13. & $\mathrm{Cs}=7 * 10^{9}(\mathrm{Abs}(\mathrm{HV}))^{-7,366}$ & 28,1 & $-9,605$ & 0,000 & 2,292 \\
\hline 14. & $\mathrm{Cs}=9,076 \mathrm{e}^{0,162 \mathrm{HH}}$ & 0,16 & 7,012 & 0,000 & 2,292 \\
\hline 15. & $\mathrm{Cs}_{\mathrm{s}}=5385065 \mathrm{e}^{0,895 \mathrm{HV}}$ & 30,9 & 0,032 & 0,974 & 2,292 \\
\hline 16. & $\mathrm{Cs}=7567568 \mathrm{e}^{1,735 \mathrm{HH}-1,486 \mathrm{HV}}$ & 53,6 & $-6,882$ & 0,000 & 2,292 \\
\hline 17. & $\mathrm{Cs}=3480,804 \mathrm{e}^{0,229(\mathrm{HH}+\mathrm{HV})}$ & 12,9 & $-0,093$ & 0,927 & 2,292 \\
\hline 18. & $\mathrm{Cs}=4 * 10^{9}(\mathrm{HH} / \mathrm{HV})^{23,745}$ & 38,4 & $-9,919$ & 0,000 & 2,292 \\
\hline
\end{tabular}

Keterangan (Remarks): Cs: Simpanan karbon (Carbon storage) (ton/ha) 
Tabel 8. Model hubungan polarisasi HH dan HV dengan biomassa pada beberapa tipe tegakan (Biomass and $H H$, HV correlation on various stand type)

\begin{tabular}{|c|c|c|c|c|c|}
\hline No & Tipe tegakan (stand type) & $\mathrm{N}$ & Range (t/ha) & Model & $\mathrm{R}^{2}(\%)$ \\
\hline 1. & Hutan Sal India (Sal forest) & 92 & $116-520$ & $\begin{aligned} \mathrm{AGB} & =8,152 \mathrm{HH}+381,4 \\
\mathrm{AGB} & =1165 \mathrm{HV}+4679\end{aligned}$ & $\begin{array}{l}1,0 \\
20\end{array}$ \\
\hline 2. & $\begin{array}{l}\text { Hutan campuran Sal (Sal } \\
\text { Mixed Forest) }\end{array}$ & 8 & $230-519$ & $\begin{array}{l}\mathrm{AGB}=45.525 \mathrm{HH}+836.01 \\
\mathrm{AGB}=-40.314 \mathrm{HV}-151.97\end{array}$ & $\begin{array}{r}7,0 \\
14,0\end{array}$ \\
\hline 3. & $\begin{array}{l}\text { Hutan campuran (Mixed } \\
\text { Forest) }\end{array}$ & 30 & $45-228$ & $\begin{array}{l}\mathrm{AGB}=-3.191 \mathrm{HH}+70.307 \\
\mathrm{AGB}=-5.9337 \mathrm{HV}+14.499\end{array}$ & $\begin{array}{l}2,0 \\
5,0\end{array}$ \\
\hline 4. & $\begin{array}{l}\text { Hutan Jamun di India (Jamun } \\
\text { forest) }\end{array}$ & 6 & $47-168$ & $\begin{array}{l}\mathrm{AGB}=37.416 \mathrm{HH}+480.81 \\
\mathrm{AGB}=51.244 \mathrm{HV}+886.44\end{array}$ & $\begin{array}{l}53,0 \\
49,0\end{array}$ \\
\hline 5. & $\begin{array}{l}\text { Hutan Khair-Sisham (Khadi } \\
\text { India }\end{array}$ & 3 & $84-250$ & $\begin{array}{l}\mathrm{AGB}=14.593 \mathrm{HH}+308.46 \\
\mathrm{AGB}=-57.801 \mathrm{HV}-826.36\end{array}$ & $\begin{array}{l}11,0 \\
86,0\end{array}$ \\
\hline 6. & $\begin{array}{l}\text { Hutan tanaman jati (teak } \\
\text { plantation) India }\end{array}$ & 30 & $63-410$ & $\begin{array}{l}\mathrm{AGB}=-20.62 \mathrm{HH}-12.71 \\
\mathrm{AGB}=25.27 \mathrm{HV}+542.7\end{array}$ & $\begin{array}{l}13,0 \\
23,0\end{array}$ \\
\hline 7. & $\begin{array}{l}\text { Hutan tanaman eukaliptus } \\
\text { (eucalyptus plantation) India }\end{array}$ & 10 & $4-162$ & $\begin{array}{l}\mathrm{AGB}=-13.114 \mathrm{HH}-44.768 \\
\mathrm{AGB}=32.857 \mathrm{HV}+634.76\end{array}$ & $\begin{array}{l}11,0 \\
68,0\end{array}$ \\
\hline 8. & $\begin{array}{l}\text { Hutan tanaman shisam (Shisam } \\
\text { plantation) }\end{array}$ & 12 & $15-114$ & $\begin{array}{l}\mathrm{AGB}=-9.787 \mathrm{HH}-37.47 \\
\mathrm{AGB}=7.139 \mathrm{HV}+173.5\end{array}$ & $\begin{array}{r}70,0 \\
6,0\end{array}$ \\
\hline 9 & Total tegakan $($ all $)$ & 191 & $4-520$ & $\begin{array}{l}\mathrm{AGB}=-4.638 \mathrm{HH}+173.3 \\
\mathrm{AGB}=37.85 \mathrm{HV}+769.2\end{array}$ & $\begin{array}{r}0,2 \\
20,0\end{array}$ \\
\hline 10. & Kelapa sawit (palm oil) & 37 & $88-250$ & $A G B=\exp \left(\frac{H V-0,013196}{0,0080139}\right)$ & 35,0 \\
\hline
\end{tabular}

Keterangan (Remarks): AGB: biomassa permukaan (above ground biomass) (ton/ha); N: jumlah plot (plot number); $\mathrm{R}^{2}$ : koefisien determinasi (coefficient of determination) (\%); No 1 9: hasil penelitian oleh Pandey et al., 2010 (result of Pandey et al.2010); No 10: hasil peneltian Morel et al. 2011 (result of Morel et al., 2011)

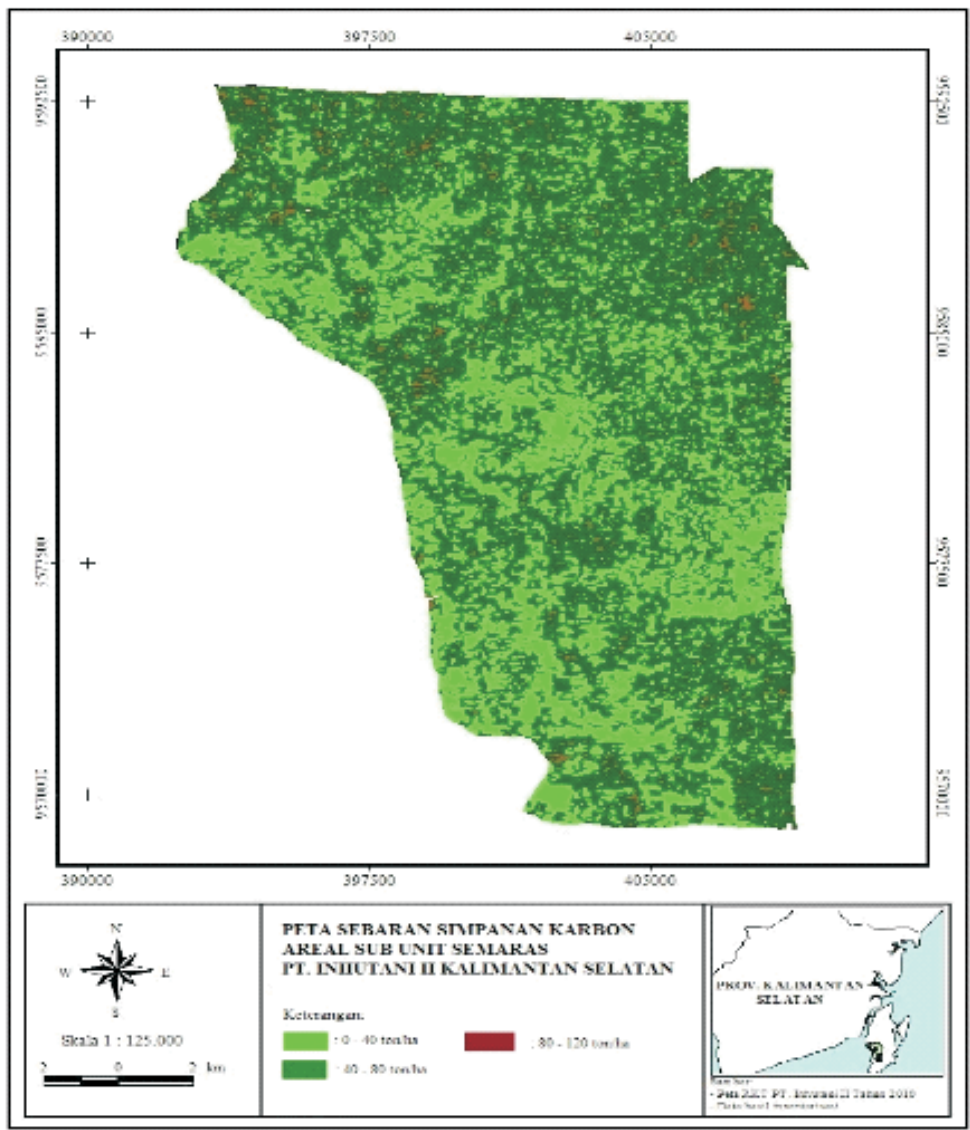

Gambar (Figure) 4. Peta sebaran simpanan karbon (Distribution of carbon stock storage site) 
Pada areal kelapa sawit dengan potensi 88 ton/ha, polarisasi HV dapat diduga dari potensi biomassa dengan $\mathrm{R}^{2}$ sebesar $63 \%$ (Morel et al., 2011). Pada tegakan dengan potensi biomasa antara $150-250$ ton/ha dan $>250$ ton/ha, hubungan polarisasi HV dengan biomassa menghasilkan $\mathrm{R}^{2} 35 \%$. Hal ini karena signal dari sensor Alos Palsar sudah tidak dapat membedakan biomassa $>80$ ton/ha atau titik saturasi sensor pada biomassa 80 ton/ha (Morel et al., 2011).

Model terpilih tersebut digunakan untuk menduga sebaran simpanan karbon di lokasi penelitian. Hasil pendugaan simpanan karbon menunjukkan simpanan karbon yang terkecil di lokasi penelitian yakni pada kisaran 80 - 120 ton/ha (Gambar 4).

\section{KESIMPULAN}

1. Potensi simpanan karbon permukaan per Ha berkisar antara 32,03 - 46,10 ton/ha dengan rata-rata 39,06 ton/ha. Potensi simpanan karbon total per Ha berkisar antara 35,48 51,01 ton/ha dengan rata-rata 43,24 ton/ha.

2. Model alometrik terbaik hubungan antara simpanan karbon dan nilai polarisasi $\mathrm{HH}$ dan HV dari citra Alos Palsar adalah Simpanan karbon $=292+2,00 \mathrm{HH}^{2}+27,1 \mathrm{HV}$ dengan koefisien determinasi sebesar $40,9 \%$.

3. Potensi sebaran simpanan karbon total terbesar berdasarkan aplikasi citra Alos Palsar yakni berkisar antara 40 - 80 ton/Ha.

\section{UCAPAN TERIMAKASIH}

Penulis mengucapkan terimakasih kepada Manajemen PT. Inhutani II Sub Unit Semaras atas kesediaan sebagai lokasi penelitian. Laboratorium Inventarisisasi Hutan IPB atas bantuannya dalam memberikan data citra Alos Palsar. Supriyadi dan Edy Suryanto (Teknisi Litkayasa Balai Penelitian Kehutanan Banjarbaru) atas bantuannya dalam pengambilan data di lapangan.

\section{DAFTAR PUSTAKA}

Berry, N.J., Phillips, O.L., Ong, R.C., Hamer, K.C. 2008. Impacts of Selective Logging on Tree Diversity Across a Rainforest Landscape: the Importance of Spatial Scale. Landscape Ecology 23, 915 - 929.
Brown, S. 1997. Estimating Biomass and Biomass Change of Tropical Forest: a Primer. Rome, Italy: FAO Forestry Paper 134.

Brown, S. 2002. Measuring Carbon in Forests: Current Status and Future Challenges. Environmental Pollution 116(2002) 363 - 372.

Chaidez, Jose de J.N. 2009. Allometric Equation and Expansion Factor for Tropical Dry Forest Trees of Eastern Sinaloa, Mexico. Tropical and Subtropical Agroecosystem 10 (2009): 45 - 52.

Dahlan, Jaya I.N.S. dan Istomo. 2005. Estimasi Karbon Tegakan Acacia mangium Willd Menggunakan Citra Landsat ETM+ dan Spot-5: Studi kasus di BKPH Parung Panjang KPH Bogor. Pertemuan Ilmiah Tahunan Mapin XIV: Pemanfaatan Efektif Penginderaan Jarak Jauh untuk Peningkatan Kesejahteraan Bangsa. Surabaya, 14 - 15 September 2005.

dos Santos, J.R., de Araujo L.S., Kuplich T.M., Freitas C.C., Dutra L.V., Ant'Anna S.J.S., and Gama F.F. 2006. Tropical Forest Biomass and Its Relationship with P-Band SAR Data. Revista Brasileira de Cartografia No 58 (01).

Draper, N. dan Smith A. 1992. Analisis Regresi Terapan. (terjemahan). PT. Gramedia Pustaka. Jakarta.

Gibbs, H.K., Brown S., Niles J.O., and Foley J.A. 2007. Monitoring and Estimating Tropical Forest Carbon Stocks: Making REDD a Reality. Environ. Res. Lett. 2 (2007) 045023 (13pp).

Hardiyanto, E.B., Ryantoko A. and Anshori S. 2000. Effect of Site Management in Acacia mangium Plantations at PT Musi Hutan Persada, South Sumatra, Indonesia. Site Management and Productivity in Tropical Plantation Forests. CIFOR : 41-49.

Heriansyah, I. 2005. Potensi Hutan Tanaman Industri dalam Mensequester Karbon: Studi Kasus di Hutan Tanaman Akasia dan Pinus. INOVASI Vol.3/XVII/Maret 2005.

Jepsen, M.R. 2006. Above-Ground Carbon Stocks in Tropical Fallows, Sarawak, Malaysia. Forest Ecology and Management 225 (2006) 287 295.

Kraenzel, M., Castillo A., Moore T., and Potvin C. 2003. Carbon Storage of Harvest-Age Teak (Tectona grandis) Plantation, Panama. Forest Ecology and Management 173 (2003): 213225.

Lazuardi, D. 2009. Model pertumbuhan dan hasil tegakan Acacia mangium Willd. tanpa penjarangan di Pulau Laut Kalimantan Selatan. [Thesis]. Universitas Gadjah Mada. Yogyakarta. 
Morel, C.A., Saatchi S.S., Malhi Y., Berry N.J., Banin, L. Burslem D., Nilus R., and Ong R.C. 2011. Estimating Aboveground Biomass in Forest and Oil Palm Plantation in Sabah, Malaysian Borneo using ALOS PALSAR Data. Forest Ecology and Management (262) 9: 1786 1798.

Nath, A.J., Das G., and Das A.K. 2009. Above Ground Standing Biomass and Carbon Storage in Village Bamboos in North East India. Biomass and Bioenergy 33 (2009) 1188 - 1196.

Navar, J. 2009. Allometric Equation for Tree Species and Carbon Stock for Forest of Northwest Mexico. Forest Ecology and Management 257 (2009): 427 - 434.

Pandey, U., Kushwaha S.P.S, Kachhwaha T.S, and Dadhwal V.K. 2010. Potential of Envisat ASAR Data for Woody Biomass Assessment. Tropical Ecology 51(1): 117-124.

Qirom, M.A. 2011. Pendugaan Persediaan Karbon dan Aplikasi Alos Palsar pada Hutan Tanaman Akasia. [Tesis]. Institut Pertanian Bogor.

Nurhayati. 2010. Pendugaan Biomassa Pohon di Atas Permukaan Tanah dan Indeks Luas Daun Menggunakan Citra Landsat TM dan Alos Palsar. [Tesis]. Institut Pertanian Bogor.

Rauste, R. 2006. Techniques for Wide-Area Mapping of Forest Biomass using Radar Data. [Dissertation]. Helsinki University of Technology.

Rokhmatuloh. 2007. Estimation of Carbon Stock Using Remote Sensing: A Case Study of Indonesia.

Saatchi, S., Houghton R.A., Dos Santos Alvala, R.C., Soares J.V., Yu Y. 2007. Distribution of Aboveground Live Biomass in the Amazon Basin. Global Change Biology 13, 816-837.

Somogyi, Z., Teobaldelli M., Federici G., Pagliari V., Grassi G., and Seufert G. 2008. Allometric
Biomass and Carbon Factors Database. $i$ Forest 1: $107-113$.

Shiver, B.D. and Borders B.E. 1996. Sampling Techniques for Forest Resource Inventory. John Wiley \& Sons, Inc.

Sritakae, A. 2006. Predictive Relation of Forest Stand Parameters from Hyperspectral Remote Sensing at Thetford-Forest the UK. Thesis. International Institute for Geo-information Science and Earth Observation Enschede, The Netherlands.

St. Clair JB. 1993. Family Differences in Equation for Predicting Biomass and Leaf area in DouglasFir (Psoudotsuga menziesii var. menziesii). Forest Science 39(4): 743 - 755.

Sulistyawati, E., Ulumuddin Y.I., Hakim D.M., Harto A.B., and Ramdhan M. 2006. Estimation of Carbon Stock at Landscape Level using Remote Sensing: a Case Study in Mount Papandayan. Enviromental Technology and Management Conference. West Java: 7 - 8 September 2006.

Wang, C. 2006. Biomass Allometric Equations for 10 Co-Occuring Tree Species in Chinese temperate Forest. Forest Ecology and Management 222: 9- 16 .

Wauters, J.B., Coudert S., Grallien E, Jonard M, and Ponette Q. 2008. Carbon Stock in Rubber Tree Plantation in Western Ghana and Mato Grosso (Brazil). Forest Ecology and Management 255 (2008): 2347-2361.

Winjum, J.K. and Schroeder P.E. 1997. Forest Plantations of the World: Their Extent, Ecological Attributes, and Carbon Storage. Agric. For. Meteorol (84): 153 - 167.

www.banjarmasin.bpk.go.id. Peta Wilayah Provinsi Kalimantan Selatan. Diunduh tanggal: $25 \mathrm{Mei}$ 2012. 
Lampiran (Appendix) 1. Luas bidang dasar masing-masing plot hasil survey pendahuluan (Basal area on each plot of preminalary survey)

\begin{tabular}{|c|c|c|c|c|c|}
\hline Plot & $\operatorname{LBDS}\left(\mathrm{cm}^{2}\right)$ & Plot & LBDS & Plot & LBDS \\
\hline 1 & $7.840,7$ & 12 & $5.636,1$ & 23 & $6.987,2$ \\
\hline 2 & $7.001,1$ & 13 & $7.012,7$ & 24 & $8.060,2$ \\
\hline 3 & $8.079,0$ & 14 & $8.022,2$ & 25 & $5.565,8$ \\
\hline 4 & $8.232,5$ & 15 & $5.953,3$ & 26 & $3.997,9$ \\
\hline 5 & $8.224,7$ & 16 & $6.414,7$ & 27 & $5.813,6$ \\
\hline 6 & $7.789,7$ & 17 & $7.035,9$ & 28 & $6.121,6$ \\
\hline 7 & $8.447,3$ & 18 & $7.998,3$ & 29 & $5.373,3$ \\
\hline 8 & $7.644,4$ & 19 & $8.428,0$ & 30 & $7.167,0$ \\
\hline 9 & $5.337,9$ & 20 & $7.537,5$ & 31 & $5.972,1$ \\
\hline 10 & $4.182,4$ & 21 & $7.122,2$ & 32 & $7.856,6$ \\
\hline 11 & $5.915,5$ & 22 & $8.556,7$ & & \\
\hline Rataan (average) & $6.916,5$ & & & & \\
\hline Stdev & $1.252,4$ & & & & \\
\hline $\mathrm{CV}$ & 18,1 & & & & \\
\hline
\end{tabular}

Keterangan (Remarks) : LBDS: Luas bidang dasar (Basal area) $\left(\mathrm{cm}^{2}\right)$; CV: Koefisien variasi (Coefficient of variation:\%); Stdev: Standar deviasi (Standard deviation) 